\title{
Study on the Physicochemical and Antioxidant Properties of Nigella Honey
}

\author{
Khan Md. Murtaja Reza Linkon, Utpal Kumar Prodhan, Md. Abdul Hakim, Md. Abdul Alim* \\ Department of Food Technology and Nutritional Science, Mawlana Bhashani Science and Technology University (MBSTU), Santosh, \\ Tangail, Bangladesh
}

\section{Email address:}

murtaja.kus@gmail.com (K. M. M. R. Linkon), utpalftns@yahoo.com (U. K. Prodhan), info.hakim.bd@gmail.com (M. A. Hakim), alim.08017@gmail.com (M. A. Alim)

\section{To cite this article:}

Khan Md. Murtaja Reza Linkon, Utpal Kumar Prodhan, Md. Abdul Hakim, Md. Abdul Alim. Study on the Physicochemical and Antioxidant Properties of Nigella Honey. International Journal of Nutrition and Food Sciences. Vol. 4, No. 2, 2015, pp. 137-140.

doi: $10.11648 /$ j.ijnfs.20150402.13

\begin{abstract}
Honey is a remarkable complex natural liquid and rich in phenolic compounds, which act as natural antioxidants and are becoming increasingly popular because of their potential role in contributing to human health. The intent of the current study was to characterize the physical, chemical, biochemical and antioxidant properties of the Nigella honey sample. The physicochemical glimpse, such as moisture, $\mathrm{pH}$, Total Soluble Solid (TSS), protein, ash, total carbohydrate, energy, Thermal Effect of Food (TEF), minerals and heavy metal content were measured applying various laboratory and mathematical techniques. Several biochemical and antioxidant tests were done to determine the antioxidant properties of Nigella honey sample. The mean moisture content was $14.331 \pm 0.377 \%$, pH content was 4.78 , Total Soluble Solid (TSS) content was $73 \%$, protein content was $0.985 \%$, mean ash content was $0.188 \pm 0.071 \%$, total carbohydrate content was $84.496 \%$, energy content was $350.4721 \mathrm{Kcal} / 100 \mathrm{~g}$, Thermal Effect of Food (TEF) content was $35.05 \mathrm{Kcal} / 100 \mathrm{~g}$ and the minerals and heavy metal content named $\mathrm{Na}, \mathrm{K}, \mathrm{Ca}, \mathrm{Mg}, \mathrm{Fe}$ and $\mathrm{Pb}$ were 558 ppm, 1063.774 ppm, 75.4 ppm, 58.8471 ppm, 344.2112 ppm and 5.6 ppm respectively. The antioxidant glimpse, such as polyphenol content was $95.5 \pm 0.0052 \mathrm{mg}$ Gallic acid $/ 50$ ml, flavonoid content was $2.66 \pm 0.000577 \mathrm{mg}$ catechin $/ 50 \mathrm{ml}$ and vitamin $\mathrm{C}$ content was $0.69 \mathrm{mg} / 100 \mathrm{ml}$, were detected, indicating that Nigella honey contributes a high antioxidant potential. Thus, the study revealed that Nigella honey is a good source of antioxidants.
\end{abstract}

Keywords: Nigella Honey, Antioxidant, Heavy Metal, Phenolic Compounds

\section{Introduction}

Honey is a sweet and flavorful product that has been consumed over the years for its high nutritional values and beneficial effects on human health. The chemical composition of honey is complex, containing approximately 181 substances including sugars, proteins, moisture, vitamins, minerals, 5-hydroxymethylfurfural (HMF), enzymes, flavonoids, phenolic acids and volatile compounds [1]. The main constituents of honey are moisture, glucose, fructose, sucrose, minerals and proteins [2 -5]. Composition of honey is rather variable and primarily depends on the floral source; however, certain external factors also play a role, such as seasonal and environmental factors and processing steps and conditions [6]. It is in use since long time both in medical and domestic needs, but recently its antioxidant property has come to limelight. With raising demand for antioxidant in the food, honey is becoming the trendy source of antioxidant since it is rich in phenolic acids, flavonoids and other antioxidants including glucose oxidase, catalase, ascorbic acid, carotenoid derivatives, organic acids, amino acids and proteins [7]. Honey contains a number of compounds and the antioxidant properties of honey are well known. The antioxidant properties of honey are derived from both enzymatic (e.g., catalase, glucose oxidase and peroxidase) and nonenzymatic substances (e.g., ascorbic acid, $\alpha$ tocopherol, carotenoids, amino acids, proteins, Maillard reaction products, flavonoids and phenolic acids) [8-10]. The amount and type of these antioxidants are largely dependent on the floral source or honey variety, and a correlation between antioxidant activity with total phenolic content has been established $[8,10]$. The dietary habit is changing day by day and the advice to take honey a day is a great saying to aid the nutritional well-being along with other food items with meal distribution patterns a day wisely [11]. Honey is the 
bees made sweet, thick, golden liquid food applying natural regurgitation and evaporation process within bees Gastrointestinal Tract (GIT) and stomach treating their consumed nectar collected from different types of flower available on the God gifted nature [6]. It has been shown in several studies that the antioxidant potential of honey is strongly correlated with the concentration of total phenolics present [12-15]. Furthermore, it has been reported that the antioxidant activityis also strongly correlated with the color of the honey, where dark colored honey has been reported to have a higher total phenolic content and consequently higher antioxidant capacities [13, 14]. There are more than 150 polyphenolic compounds that have been reported, including phenolic acids, flavonoids, flavonols, catechins and cinnamic acid derivatives [16].In Islam, there is an entire Surah in the Qur'an called al-Nahl (the Bee). According to hadith, Prophet Muhammad (Sm.) strongly recommended honey for healing purposes. The Qur'an promotes honey as a nutritious and healthy food. Below is the English translation of those specific verses."And thy Lord taught the Bee to build its cells in hills, on trees, and in (men's) habitations; Then to eat of all the produce (of the earth), and find with skill the spacious paths of its Lord: there issues from within their bodies a drink of varying colors, wherein is healing for men: verily in this is a sign for those who give thought" [17]. As the honey has a potentiality to act as an antioxidant the objectives of the study were to evaluate the physicochemical and antioxidant properties of Nigella honey.

\section{Methodology}

\subsection{Place of Experiment and Sample Collection}

The study was carried out at Food Technology and Nutritional Science (FTNS) laboratory of Mawlana Bhashani Science and Technology University (MBSTU), Santosh, Tangail, Biochemistry and Molecular Biology laboratory of Jahangirnagar University (JU) and Bangladesh Council of Scientific and Industrial Research (BCSIR), Dhanmondi, Dhaka.The topic sample, Nigella honey (Nigella sativa) by name was collected from Afsar Ali, Tangail district unit Bangladesh Apiculturist Welfare Association (BAWA) president and also a renowned honey cultivator at Sagardighi of Ghatail upazila in Tangail. The study was continued from the $2^{\text {nd }}$ week of July 2013 to the $1^{\text {st }}$ week of February 2014 based on the selected honey sample.

\subsection{Physicochemical Quality Analysis}

Estimation of moisture, protein, ash content, Carbohydrate, Energy, TEF and vitamin $\mathrm{C}$ were determined by AOAC method-2005 [18], The TSS of the samples was determined by a hand refractometer, Minerals and heavy metal content of sample were determined by Atomic Absorption Spectrophotometer (AAS) and Flame Emission Spectrophotometer, $\mathrm{Na}$ and $\mathrm{K}$ were determined by Flame Emission Spectrophotometer, The total polyphenol was determined applying the Folin-Ciocalteu's method, The total flavonoid was determined applying Aluminum chloride colorimetric assay method, Absorption Spectrophotometer was used to measure Calcium (Ca), Magnesium $(\mathrm{Mg})$, Iron $(\mathrm{Fe})$ and Lead $(\mathrm{Pb})[18]$.

\subsection{Data Analysis}

Statistical mean, median, mode, standard deviation (SD) and range were determined using SPSS 16 programme. For linear, tabular, chart and graphical representation, Microsoft Word and Microsoft Excel were used in the respective arena.

\section{Results and Discussion}

The analysis of the physicochemical and antioxidant properties of nigella honey was done according to the framework discussed earlier and from the results gained the following discussion can be sketched.

\subsection{Nutrient Contents of Nigella Honey}

Table 1 shows the nutrient contents of Nigella honey and fresh Nigella honey was analyzed for moisture, protein, ash, total carbohydrate and the TSS contents. The results were represented Nigella honey contained 14.331 \pm 0.377 percentage moisture, $0.985 \pm 0.051$ percentage protein, $0.188 \pm 0.071$ percentage ash, 84.49 percentage total carbohydrate and 73 percentage TSS. The mean total moisture content of Nigalla honey sample was $14.331 \%$ contributing within the limit $\leq 20 \%$ recommended by the international quality regulations [19]. The investigated Nigalla honey sample was of good quality, as indicated by the low moisture content. The Nigella honey showed to have high TSS content. The honey contributes an ample of sugar concentration suspended on the natural honey solution and represents the strength of the solution. Low protein content is desired for crisp, tender products eg.snacks whereas the high protein content desired to get product with chewy texture. The ash is the measure of the total mineral content of selected honey sample was in ample amount. It's the essential component of food in care of catalyst over various body functioning reactions to sustain sound health. There was high amount of available carbohydrate $(84.75 \%)$ in the respective honey sample. Available carbohydrate is the premier fuel to fuel alcohol formation in fermentation process [20].

Table 1. Nutrient contents of Nigella honey

\begin{tabular}{ll}
\hline Nutrient contents & Amounts ( Percentage ) \\
\hline Moisture & $14.331 \pm 0.377$ \\
protein & $0.985 \pm 0.051$ \\
Ash & $0.188 \pm 0.071$ \\
Total Carbohydrate & 84.496 \\
TSS & 73 \\
\hline
\end{tabular}

\subsection{Minerals and Heavy Metal Analysis}

From the analysis of the selected specimen, the measured minerals and heavy metal contents were presented in Table 2. 
The analysis showed the composition of major minerals $\mathrm{Na}$ 558 ppm, K 1063.774 ppm, Ca 75.4 ppm, Mg 58.8471 ppm, essential mineral Fe $344.2112 \mathrm{ppm}$ and heavy metal $\mathrm{Pb} 5.6$ ppm. The lower amount $\mathrm{Na}$ and $\mathrm{K}$ content measured in Nigella honey and they help in the smooth continuation of ETS system in the body. The $\mathrm{Ca}, \mathrm{Mg}, \mathrm{Fe}$ and $\mathrm{Pb}$ content of Nigella sample were measured low in concentration and they are growth enhancer of the body and heavy metal $\mathrm{Pb}$ is detrimental for health if exceeds acceptable range in the sample taken.

Table 2. Minerals and heavy metal contents of Nigella honey.

\begin{tabular}{llllll}
\hline $\begin{array}{l}\text { Major } \\
\text { minerals }\end{array}$ & $\begin{array}{l}\text { Amounts } \\
\text { (ppm) }\end{array}$ & $\begin{array}{l}\text { Essential } \\
\text { mineral }\end{array}$ & $\begin{array}{l}\text { Amount } \\
\text { (ppm) }\end{array}$ & $\begin{array}{l}\text { Heavy } \\
\text { metal }\end{array}$ & $\begin{array}{l}\text { Amount } \\
\text { (ppm) }\end{array}$ \\
\hline $\mathrm{Na}$ & 558 & $\mathrm{Fe}$ & 344.2112 & $\mathrm{~Pb}$ & 5.6 \\
$\mathrm{~K}$ & 1063.774 & & & & \\
$\mathrm{Ca}$ & 75.4 & & & & \\
$\mathrm{Mg}$ & 58.8471 & & & & \\
\hline
\end{tabular}

\subsection{Biochemical Analysis}

From the analysis of the selected specimen the $\mathrm{pH}$ content of Nigella honey was obtained 4.78 at $27^{\circ} \mathrm{C}$ room temperature.

\subsection{Energy Boosting Analysis}

The energy content and the TEF content were analyzed applying laboratory plus mathematical techniques. From the investigation, the dietary energy content was found 350.4721 $\mathrm{Kcal} / 100 \mathrm{~g}$ and the TEF content was $35.05 \mathrm{Kcal} / 100 \mathrm{~g}$, indicating the Nigella honey was the prime energy booster for health consumption.

\subsection{Antioxidant Analysis}

The antioxidant contents were analyzed applying laboratory plus statistical techniques. The results were presented in Table 3. From the analysis, the phenolic content was in Nigella honey sample $95.5 \mathrm{mg}$ gallic acid $50 \mathrm{ml}$, flavonoid content was $2.66 \mathrm{mg}$ catechin $/ 50 \mathrm{ml}$ and the vitamin $\mathrm{C}$ content was $0.69 \mathrm{mg} / 100 \mathrm{ml}$. There was high phenolic acid content found only $4.5 \mathrm{mg}$ gallic acid $50 \mathrm{ml}$ lesser than that of $100 \mathrm{mg}$ gallic acid $50 \mathrm{ml}$ found in Nigella honey. The concentration and the type of polyphenolic substances in honey are variable and are reported to be dependent on the floral origin of honey samples. The high mean total phenolic content in Nigella honey indicates the Bangladeshi honeys are in good antioxidant properties. The darker colored honey is the phenolic compounds booster than that of light colored honey [21]. The antioxidant activity of natural honeys depends largely on their chemical composition, such as phenolics, enzymes, organic acids, amino acids and Millard reaction products [22]. The flavonoids are low molecular weight phenolic compounds to lead the vital factor for aroma and antioxidant properties of honey. The antioxidant activities of natural honeys mostly rely on their chemical composition, i.e., flavonoids, organic acids, carotenoids as well as their source of origin [23]
Table 3. Antioxidant contents of Nigella honey.

\begin{tabular}{ll}
\hline Parameter & Amount \\
\hline Polyphenol & $95.5 \pm 0.00529 \mathrm{mg}$ gallic acid $/ 50 \mathrm{ml}$ \\
Flavonoid & $2.66 \pm 0.000577 \mathrm{mg}_{\text {catechin }} / 50 \mathrm{ml}$ \\
Vitamin C & $0.69 \mathrm{mg} / 100 \mathrm{ml}$ \\
\hline
\end{tabular}

\section{Conclusion}

The study investigates the positive presence of Nigella honey showing the first-class physicochemical potentials, pointing the low moisture content, $\mathrm{pH}$, high TSS, the lowest protein, ash, minerals and heavy metal content as well as the first-class antioxidant potentials, pointing the high polyphenols, flavonoids and vitamin $\mathrm{C}$ content.

\section{References}

[1] Al-Mamary, M.; Al-Meeri, A.; Al-Habori, M. Antioxidant activities and total phenolics of different types of honey. Nutr. Res. 2002, 22, 1041-1047.

[2] Kirk, R.; Sawyer, R. Herbs and spices, salt. Composition and Analysis of Foods, 9th ed.; Longman Scientific and Technical: Harlow, UK, 1991; pp. 391-429.

[3] White, J.W. Composition of honey. In Honey, a Comprehensive Survey; Crane, E., Ed.; Crane, Russak: New York, NY, USA, 1975; pp. 157-206.Bryant, Vaughn M., Jr. (2001). Pollen Contents of Honey, CAP Newsletter24 (1): 10 24.

[4] Whitmyre, Val. The Plight of the Honeybees. University of California. April 14, 2007.

[5] Honey Color and Flavor". National Honey Board. Retrieved 3 February 2011. Wildflower honey is often used to describe honey from miscellaneous and undefined flower sources.

[6] Waikato Honey Research Unit. June 02, 2007.

[7] Sharma, Rajeev (2005). Improve your Health! With Honey. Diamond Pocket Books. pp. 33-. ISBN 978-81-288-0920-0.

[8] Al, M.L.; Daniel, D.; Moise, A.; Bobis, O.; Laslo, L.; Bogdanov, S. Physico-chemical and bioactive properties of different floral origin honeys from Romania. Food Chem. 2009, 112, 863-867.

[9] Ferreira, I.C.F.R.; Aires, E.; Barreira, J.C.M.; Estevinho, L.M. Antioxidant activity of portuguese honey samples: Different contributions of the entire honey and phenolic extract. Food Chem. 2009, 114, 1438-1443.

[10] Gheldof, N.; Engeseth, N.J. Antioxidant capacity of honeys from various floral sources based on the determination of oxygen radical absorbance capacity and inhibition of in vitro lipoprotein oxidation in human serum samples. J. Agric. Food Chem. 2002, 50, 3050-3055.

[11] The Colours of Honey. Mieliditalia.it. Retrieved on 6 February 2011.

[12] Aljadi AM, Kamaruddin MY: Evaluation of the phenolic contents and antioxidant capacities of two Malaysian floral honeys. Food Chem 2004, 85(4):513-518. 
[13] Beretta G, Granata P, Ferrero M, Orioli M: Maf: standardization of antioxidant properties of honey by a combination of spectrophotometric/fluorimetric assays and chemometrics. Anal Chim Acta 2005, 533:185-191.

[14] Bertoncelj J, Dobersek U, Jamnik M, Golob T: Evaluation of the phenolic content, antioxidant activity and colour of Slovenian honey. Food Chem 2007, 105:822-828.

[15] Meda A, Lamien CE, Romito M, Millogo J, Nacoulma OG: Determination of the total phenolic, flavonoid and proline contents in Burkina Fasan honey, as well as their radical scavenging activiity. Food Chem 2005, 91:571-577.

[16] Ferreira ICFR, Aires E, Barreira JCM, Estevinho LM: Antioxidant activity of Portuguese honey samples: different contributions of the entire honey and phenolic extract. Food Chem 2009, 114:1438-1443.

[17] Yusuf 'Ali, 'Abdullah. A Nahl, Al-Quran Chapter 16 (The Bee) quoted from "The Holy Qur'an: Original Arabic Text with English Translation \& Selected Commentaries". Saba Islamic Media. May 20, 2013.
[18] AOAC (2005) Official methods of Analysis of AOAC, International, Washington, DC: Association of Official Analytical Chemist (1990). 16:1546.

[19] Codex Alimentarius Commission. Revise codex standard for honey. Codex Standards 12-1982, Rev.1 (1987), Rev.2 (2001)1, COMESA/FDHS 002:2004.

[20] Bahl, Arun and Bahl, B. S. A Textbook of Organic Chemistry.

[21] Jasicka-Misiak, I.; Poliwoda, A.; DereÅ, M.; Kafarski, P. Phenolic compounds and abscisic acid as potential markers for the floral origin of two polish unifloral honeys. Food Chem.2011. 520-550.

[22] Meda, A.; Lamien, C.E.; Romito, M.; Millogo, J.; Nacoulma, O.G. Determination of the total phenolic, flavonoid and proline contents in Burkina Fasan honey, as well as their radical scavenging activiity. Food Chem. 2005, 91, 571-577.

[23] Socha, R.; Juszczak, L.; Pietrzyk, S.; Fortuna, T. Antioxidant activity and phenolic composition of herb honeys. Food Chem. 2009, 113, 568-574. 